\title{
https://doi.org/10.46813/2021-133-119 \\ ANALYSIS OF URANIUM MOBILITY AND CONCENTRATION PROCESS IN OBJECTS OF ENVIRONMENT AND PATIENTS' KIDNEY STONES IN KHARKIV REGION
}

\author{
N.P. Dikiy', V.N. Lisovoy' ${ }^{2}$,E.P. Bereznyak ${ }^{1}$, S.M. Kolupayev', Yu.V. Lyashko', \\ E.P. Medvedeva ${ }^{1}$, D.V. Medvedev ${ }^{1}$, Y.S. Hodyreva ${ }^{1}$ \\ ${ }^{1}$ National Science Center “Kharkov Institute of Physics and Technology”, Kharkiv, Ukraine; \\ ${ }^{2}$ Kharkiv National Medical University, Kharkiv, Ukraine \\ E-mail: ndikiy@kipt.kharkov.ua
}

The specific activity of ${ }^{235} \mathrm{U}$ and content of native uranium for the Kharkiv region in drinking water, soil, roots, the leaf of hydrophyte "Pistia stratiotes" and the samples of kidney stones obtained from patients with urolithiasis were measuring by using gamma activation analysis on linac accelerator of NSC KIPT. The whole sample contained alpha-emitter uranium.

PACS: 87.23.-n; 92.40.Oj

\section{INTRODUCTION}

The problems of actinides migration and distribution in different medium are very importance and actual. Actinides geochemical mobility is higher in contaminated ecosystem.

A substantial public discussion was devoted to influencing of sulfate, phosphate, and carbonate complexation on uranium distribution in the ecosystem and on the health effects. Depleted uranium is less radioactive than natural uranium. The risks from the chemical toxicity of uranium and its different effects on human health and disease considered [1].

Natural uranium found in water, soil, and rocks with an average concentration in the earth's crust of $2.7 \mathrm{mg} / \mathrm{kg}$, or $0.0004 \%$. It occurs as a mixture of three radioactive isotopes ${ }^{238} \mathrm{U}(99.27 \%),{ }^{235} \mathrm{U}(0.72 \%)$, and ${ }^{234} \mathrm{U}(0.0055 \%)$ [2]. Radioactivity of natural uranium $25.280 \mathrm{~Bq} / \mathrm{g}$ depends on the percentage and on specific activity of the three isotopes ${ }^{238} \mathrm{U}(12.455 \mathrm{~Bq} / \mathrm{g}),{ }^{235} \mathrm{U}$ $(80.011 \mathrm{~Bq} / \mathrm{g})$, and ${ }^{234} \mathrm{U}\left(2.31 \cdot 10^{-6} \mathrm{~Bq} / \mathrm{g}\right)$. Uranium is present in oxidation states $0,+2,+3,+4,+5$, and +6 , being the prevalent forms the tetravalent U(IV), found in most minerals and U(VI), which represents the more suitable state [3]. Elemental uranium dissolve in the strong acids $\left(\mathrm{H}_{2} \mathrm{SO}_{4}\right)$, while it is stable in a strong base solution. Divalent uranium compounds $(+2)$, as UO exist only in the solid-state [4]. Trivalent compounds readily oxidized in water solution. Pentavalent uranium is compounds oxidized by oxygen in presence of air, and gives tetravalent and hexavalent by disproportionation in absence of air. The tetravalent uranium compounds, stable in the absence of air, comprise the oxide $\mathrm{UO}_{2}$, different salts and basic salt as $\mathrm{UO}\left(\mathrm{NO}_{3}\right)_{2}$ and $\mathrm{UOCl}_{2}$. The chemistry of uranyl $\left(\mathrm{UO}_{2}^{+2}\right)$ cation is the most dangerous for the environmental and biological behavior. Uranyl cation is a "yard" cation that strongly interacts with inorganic oxygen donor ligands and organic ligands like carboxylic and amino carboxylic acids, phenols and biological substances [5]. The complex formation, equilibrium involving uranyl complexes and coordination of number inorganic and organic ligands are very importance for examination of determinant for environmental fate of $\left(\mathrm{UO}_{2}{ }^{+2}\right)$, and its absorption and bioavailability in humans.

The aim of the present study is to investigate the uranium mobility and concentration process in drinking water, soil, aquatic plant (hydrophyte) and patients' kidney stones in the region of Kharkiv.

\section{MATERIALS AND METHODS}

There are the samples of drinking water, soils from neighborhood in Kharkiv, river plant "Pistia stratiotes" and kidney stones surgically removed from 24 patients (the age group was 40-68).

The determination of uranium content in samples was performed by gamma spectrometer method on $\mathrm{Ge}(\mathrm{Li})$-detector with the volume of $50 \mathrm{~cm}^{3}$ and resolution of 3.2 at $1332 \mathrm{keV}$ line. To reduce the influence of background, the detector is equipped with a three-layer $\mathrm{Pb}-\mathrm{Cu}-\mathrm{Al}$ protection. The more significant error is for ${ }^{238} \mathrm{U}$, the activity of which was calculated from activity of ${ }^{235} \mathrm{U}$ (line of $186 \mathrm{keV}$ is equal sums of line from ${ }^{226} \mathrm{Ra}$ $\left.+{ }^{235} \mathrm{U}\right)$. The errors of measurements were from 7 to $25 \%$.

Samples irradiated by bremsstrahlung from the linear accelerator electron NSC KIPT with energy $23 \mathrm{MeV}$ and current $500 \mu \mathrm{A}$. Activation of samples carried out on air, the temperature of samples in the course of the activation did not exceed $40^{\circ} \mathrm{C}$. The limit of detection elements for photo activation analysis was $\left(10^{-4} \ldots 10^{-7}\right) \mathrm{wt} \%$. Gamma-activation analyses are no destroying for native samples.

The IR-spectroscopy is suitable method, which give information about the composition of kidney stones and identify not only the molecular species present in stone but also the crystalline form.

The ${ }^{235} \mathrm{U}$ yield in the nuclear reaction calculated with the help of the program complex PENELOPE.

As experimental model, drinking water (5..10) 1 was chosen with $\mathrm{pH}=6.8$. The $\mathrm{Fe}_{2} \mathrm{O}_{3}$ nanoparticles used as sorbent for ${ }^{235} \mathrm{U}$ in drinking water relativity $\mathrm{FeCl}_{3}$.

Samples of soil $(15 \times 15 \mathrm{~cm}$ and $\mathrm{h}=10 \mathrm{~cm})$ from the neighborhood in Kharkiv on virgin soil or in the forest. Two samples were took on arable land. Soil samples dried at room temperature then sieved through a $1-\mathrm{mm}$ 
mesh to remove the roots of plants and stones and homogenized prior to analysis.

Samples of "Pistia stratiotes" (dry roots and leaf) from the Seversky Donets were taken in October. Investigation of radionuclide activity in dry samples was in air.

The kidney stones from 24 patients of both sexes washed many times with distilled water, and then completely dried at room temperature. After drying kidney stones crushed in agate mortar. For IR-spectroscopy analysis, the samples were prepared in the form of transparently compressed tablets from a mixture of $\mathrm{KBr}$, which served as the matrix and the test substance (in amount of $1 \%, 100 \mathrm{mg}$ sample). The tablets had a rectangular shape and of sizes $25 \times 5 \mathrm{~mm}$. The pressure was $9200 \mathrm{~kg} / \mathrm{cm}^{2}$. To exclude the absorption bands of the matrix, a tablet of pure potassium bromide, pre dried at $180^{\circ} \mathrm{C}$ for $10 \mathrm{~h}$, placed in comparison channel of the device. The powders were ground and mixed in a special closed box; pressing performed immediately before measuring spectra. The evaluation carried out on the spectrum of polystyrene with a known frequency of absorption maxima. Correction averaged $10 \ldots 5 \mathrm{~cm}^{-1}$. The IR-spectrometer IRS-29 (LOMO) used to record absorption spectra in the infrared range. The spectra were recorded in the spectral range $4000 \ldots 400 \mathrm{~cm}^{-1}$ (middle infrared region) [6, 7].

The investigation of the kidney stones was performed in accordance with the principles of the Declaration of Helsinki and approved by the Ethics Committee of V.I. Shapoval Regional Clinical Centre of Urology and Nephrology. Before collecting stone samples, patients were informed about the aim, methods of the study, and provided the written informed consent.

\section{RESULTS AND DISCUSSION}

The production of activity maximum of ${ }^{235,238} \mathrm{U}$ sorption was with use nanoparticles $\mathrm{Fe}_{2} \mathrm{O}_{3}(40 \mathrm{~nm}) \mathrm{pH}=3.2$. In the studied ecosystems, $\mathrm{Fe}$-compounds are major sorbents of uranium during migration and concentration process [8].

The specific activity of ${ }^{235,238} \mathrm{U}$ were $1.2 \cdot 10^{-6}$ and $1.8 \cdot 10^{-6} \mathrm{Bk} / \mathrm{dm}^{3}$. There were ${ }^{90} \mathrm{Sr}-7.7 \cdot 10^{-4},{ }^{232} \mathrm{Th}-$ $1.1 \cdot 10^{-7} \mathrm{Bk} / \mathrm{dm}^{3}$ in drinking water. The low-level ${ }^{235,238} \mathrm{U}$ sorption was connected with there is uranium in drinking water as stable anion tri-carbonate complexes.

On Fig. 1 shows the gamma spectrum of soil sample. In general, uranium is more closely associate with iron and manganese, due to its strong sorption by iron oxides. The ${ }^{238} \mathrm{U}$ content in different types soil has differences, for example: serozems $-31.5 \mathrm{~Bq} / \mathrm{kg}$, gray-brown - 27.8 Bq/kg, chestnut - 26.6 Bq/kg, chernozems $21.6 \mathrm{~Bq} / \mathrm{kg}$, gray forest $-17.8 \mathrm{~Bq} / \mathrm{kg}$, sod-podzolic 15.2 Bq/kg, podzolic $-8.9 \mathrm{~Bq} / \mathrm{kg}$, peaty $-6.3 \mathrm{~Bq} / \mathrm{kg}$.

Therefore, for the Kharkiv region there are the series actinides migration $\mathrm{Ra}>\mathrm{U}>\mathrm{Th}$.

On Fig. 2 the gamma spectra of the irradiated sample of roots of "Pistia stratiotes" are given. There are radionuclides of these samples $\left({ }^{40} \mathrm{~K},{ }^{131} \mathrm{I},{ }^{7} \mathrm{Be},{ }^{226} \mathrm{Ra}\right.$, $\left.{ }^{228} \mathrm{Ac},{ }^{214} \mathrm{~Pb},{ }^{214} \mathrm{Bi},{ }^{208} \mathrm{Tl},{ }^{212} \mathrm{~Pb},{ }^{137} \mathrm{Cs},{ }^{235} \mathrm{U}\right)$. "Pistia statiotes" content of elements in leaf and roots has the peculiarities. The content of elements in root there are $\mathrm{Mn}$,
$\mathrm{Co}, \mathrm{Ni}, \mathrm{Mo}, \mathrm{I}, \mathrm{Pb}, \mathrm{As}$, and U. The leaf include element $\mathrm{U}$ too. The content $\mathrm{U}$ in root is $3.74 \cdot 10^{-6} \mathrm{~g} / \mathrm{g}$, in leaf $5.27 \cdot 10^{-7} \mathrm{~g} / \mathrm{g}$.

According these results uranium impregnated not only water, soil and plants and it becomes hazardous to biological organisms in a large geographic area. High levels of urinary excretion of uranium are frequently associated with accumulation of uranium in the kidneys [9]. Renal storage occurs after uranium intakes $(10 \ldots .50 \mu \mathrm{g} / \mathrm{kg}$ body weight) and may produce chemical changes in the proximal renal tubules and indicate damage in renal glomeruli [10]. The elevation concentration of uranium in drinking water provide some evidence of adverse renal effects as assessed by biomarkers of proximal tubule damage. The kidney and in particular epithelial cells of the proximal tubules may be the target, for example, of uranium and of others actinides. The precise mechanism nephrotoxicity by uranium has not recognized. However, the inflammatory process as usually is escorting the formation of reactive oxygen species, followed by lipid peroxidation and glutathione oxidation in the cell membrane [11]. It is possible that uranium - induced nephrotoxicity is link to impairment of electron transfer to free radical products $\left(\mathrm{R}^{\bullet}, \mathrm{RO}^{\circ}\right.$, $\mathrm{ROO}^{\circ}, \mathrm{H}_{2} \mathrm{O}_{2}$ ) and to the oxidative cell stress. The oxidative dysfunction might play a fundamental role in renal toxicity to uranium and others actinides. Uraniuminduced nephrotoxicity might be one of possibility in formation of kidney stones.

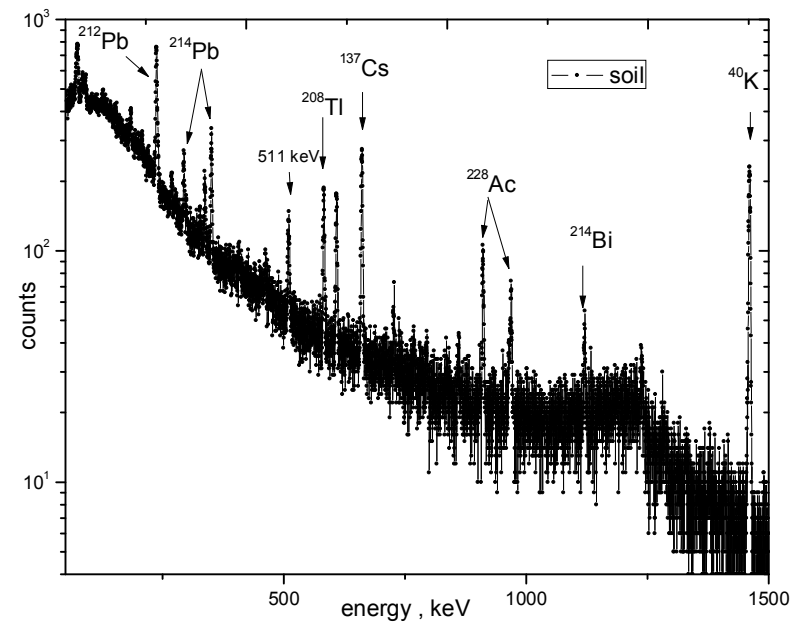

Fig. 1. The energy spectrum of soil sample

An important chemical property of uranium is its strong reducing ability. The aqueous solutions of $\mathrm{UO}_{4}$ hydrolyzed. In bone and tooth's uranium is being deposited on the surface of smallest hydroxyapatite crystals by ion exchange of $\mathrm{Ca}^{+2}$ ions labile form per $\mathrm{UO}_{2}{ }^{+2}$. Each ion of $\mathrm{UO}_{2}^{+2}$ strongly binds with two phosphate groups on the surface of the crystals, releasing two $\mathrm{Ca}^{+2}$ ions [12]. The form of uranium ions in the body is $\mathrm{UO}_{2}{ }^{+2}$. Uranium and other actinides are alpha emitters and they long detained in the human body.

The average content of uranium in some types of kidney stones (calcium oxalates, calcium oxalate dehydrates, calcium phosphates, urate, magnesium ammonium phosphate, pure uric acid and others) was performed using $\mathrm{Ge}(\mathrm{Li})$-detector relativity of standarduranium and composed from 1 to $100 \mathrm{ppb}$. 


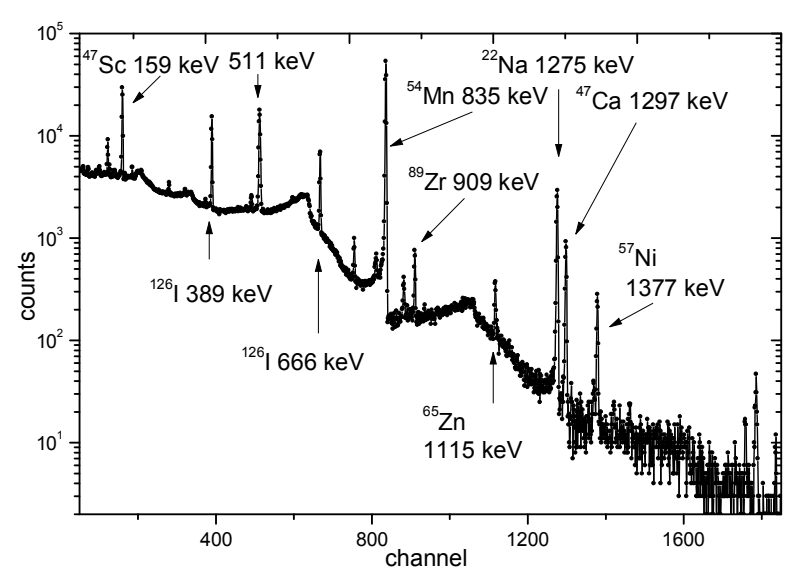

Fig. 2. The energy spectrum of root "Pistia stratiotes" after irradiation on electron accelerator

The wide range of chemical compounds identified in the samples of different types of kidney stones. There are whevellite (calcium oxalate monohydrate $\mathrm{CaC}_{2} \mathrm{O}_{4} \cdot \mathrm{H}_{2} \mathrm{O}$, wheddelite $-\mathrm{CaC}_{2} \mathrm{O}_{4} \cdot 2 \mathrm{H}_{2} \mathrm{O}$, hydroxyapatite $-\mathrm{Ca}_{10}\left(\mathrm{PO}_{4}\right)_{6}(\mathrm{OH})_{2}$, uric acid $-\mathrm{C}_{5} \mathrm{H}_{4} \mathrm{~N}_{4} \mathrm{O}_{3}$, aragonite $-\mathrm{CaCO}_{3}$ and others mixed compounds.
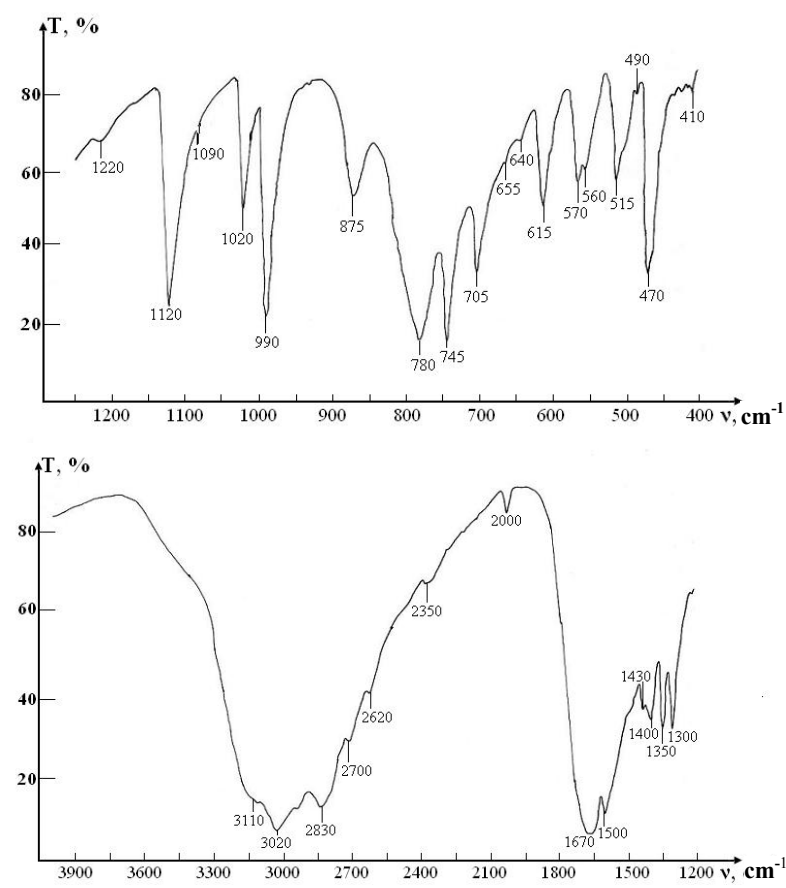

Fig. 3. IR-absorption spectra the sample kidney stones N1

Fig. 3 show IR-spectra the sample of kidney stones N1 with bands corresponding to different types vibration of main structural fragments of organic and nonorganic compounds with sharp maximums $(415,440,470$, $515,560,600,775,955,1030,1100,1310,1400,1600$, $\left.3100,3300,3420 \mathrm{~cm}^{-1}\right)$. There are wide maximums which are characteristic into whevellite $(\mathrm{O}-\mathrm{C}=\mathrm{O}) 415$, $440,470,560,600,1030 \mathrm{~cm}^{-1}(70 \%)$, into phosphates $\left(\mathrm{PO}_{4}^{-3}\right), 515,775,955,1310 \mathrm{~cm}^{-1}-$ into apatite $(20 \%)$.

Fig. 4 show IR-spectra the samples of kidney stones N2. The characteristic bands namely 420, 440, 470, 480, $515,640,660,775,870,950,1080,1300,1330,1360$, $1600,3060,3130,3240,3330,3420 \mathrm{~cm}^{-1}$ are very similar with the sample N1.
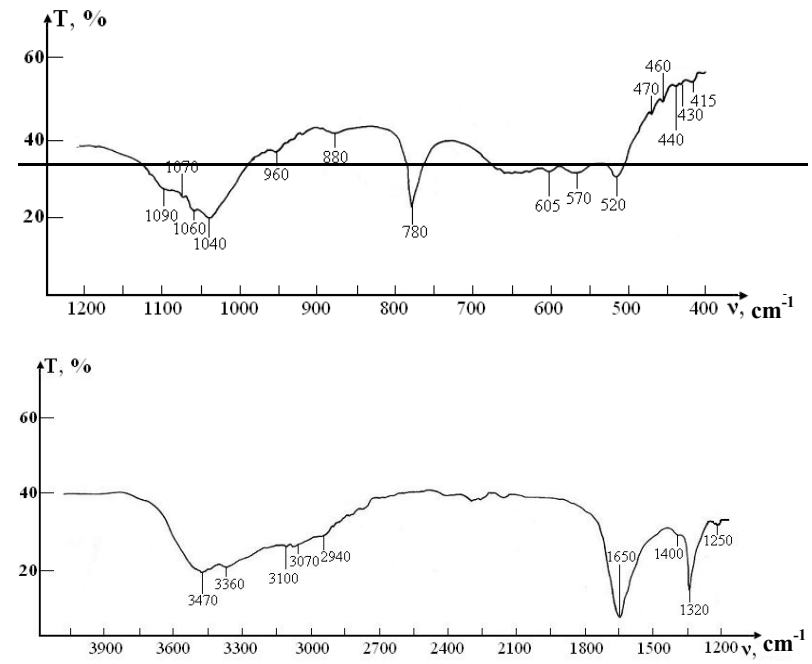

Fig. 4. IR-absorption spectra the sample kidney stones N2

\section{CONCLUSIONS}

The specific activity of ${ }^{235} \mathrm{U}$ and content of native $\mathrm{U}$ for the Kharkiv region in drinking water, soil, of roots, leaf of hydrophyte "Pistia stratiotes" and the samples of kidney stones obtained from patients with urolithiasis carried out by using gamma-activation analysis on linac accelerator of NSC KIPT.

The ${ }^{235,238} \mathrm{U}$ activity is one of dangerous actinide. It was register in whole research samples the following level:

for drinking water - from $1.2 \cdot 10^{-6}$ to $1.8 \cdot 10^{-6} \mathrm{~Bq} / \mathrm{dm}^{3}$;

for soil - 26.6 .. 8.9 Bq/kg;

for native $U$ in the root of "Pistia stratiotes" $3.74 \cdot 10^{-6} \mathrm{~g} / \mathrm{g}$;

in the leaf of "Pistia stratiotes" $-5.27 \cdot 10^{-7} \mathrm{~g} / \mathrm{g}$;

the activity of ${ }^{235} \mathrm{U}$ in the root "Pistia stratiotes" $2.6 \cdot 10^{-8} \mathrm{~Bq} / \mathrm{kg}$;

For sample of kidney stones from 1 to $100 \mathrm{ppb}$.

The infrared spectral analysis the whole samples have the common feature for all types of kidney stones in patients of the Kharkiv region.

The level of the uranium in native $U$ and ${ }^{235} \mathrm{U}$ not exceeds the background value for the Kharkiv region.

\section{REFERENCES}

1. S. Shawky. Depleted uranium: an overview of its properties and health effects // Eastern Mediterranean Health Journal. 2002, v. 8, p. 432-439.

2. E.S. Craft, A.W. Abu-Qare, M.M. Flaherty, et al. Depleted and natural uranium: chemistry and toxicological effects // J. Toxicology and Environmental Health, Part B. 2004, v. 7 (4), p. 297-317.

3. D. Banks, O. Royset, T. Strand, et al. Radioelement (U, Th, Rn) concentrations in Norwegian bedrock groundwaters // Environmental Geology. 1995, v. 25, p. $165-180$.

4. I. Grenthe, J. Drożdżynński, T. Fujino, et al. The chemistry of the actinide and transactinide elements, Springer. 2008, p. 253-698.

5. S. Berto, F. Crea, P.G. Daniele, et al. Advances in the investigation of dioxouranium (VI) complexes of 
interest for natural fluids // Coordination Chemistry Reviews. 2012, v. 256, p. 63-81.

6. V.C. Farmer. The infrared spectra of minerals. Mineralogical Society, Monograph 4, London, 1974, 359 p.

7. E. Larsen, G. Berman. Definition transparent mineral under a microscope. M.: Publishing house "Bowels", 1965, 464 p.

8. N.P. Dikiy, Yu.V. Lyashko, E.P. Medvedeva, et al. Nanostructured materials for the sorption of uranium from aqueous media // Proceeding XX Inter. conf. on physics radiation phenomena and material, 1015 September 2012 years, Crimea. 2012, p. 159-160.

9. X. Arzuaga, S.H. Rieth, A. Bathija, et al. Renal effects of exposure to natural and depleted uranium: a review of the epidemiologic and experimental data // J. of Toxicology and Environmental Health, Part B. 2010, v. 13, p. 527-545.
10. N. Priest. Toxicity of depleted uranium // The Lancet. 2001, v. 357, p. 244-246.

11. V.P. Starenkii, L.I. Vasilev, Iu.V Nikitchenko, et al. Effect of subtherapeutic doses of docetaxel (taxotere) on the efficacy of radiotherapy and prooxidant-antioxidant balance in rats with Guerin's carcinoma // Radiats. Biol. Radioecol. 2003, v. 43(6), p. 640-646.

12. N.P. Dikiy, E.P. Bereznyak, S.N. Grigorov, et al. Variation of impurity element content, structure and phase composition of the teeth at inflammatory odontogenic diseases // Problems of Atomic Science and Technology. Series "Nuclear Physics Investigations”. 2019, № 3, p. 47-52.

Article received 08.02.2021

\section{АНАЛИЗ МИГРАЦИОННОЙ СПОСОБНОСТИ И КОНЦЕНТРИРОВАНИЯ УРАНА В ОБЫЕКТАХ ОКРУЖАЮЩЕЙ СРЕДЫ И ПОЧЕЧНЫХ КАМНЯХ ПАЦИЕНТОВ В ХАРЬКОВСКОМ РЕГИОНЕ \\ Н.П. Дикий, В.Н. Лисовой, Е.П. Березняк, С.М. Колупаев, Ю.В. Ляшко, Е.П. Медведева, Д.В. Медведев, Н.С. Ходырева}

Проведен гамма-активационный анализ на ЛУЭ ННЦ ХФТИ определения содержания природного урана и удельной активности ${ }^{235} \mathrm{U}$ в объектах окружающей среды (воде, почве, водном растении (гидрофит)), а также в почечных камнях пациентов. Во всех исследуемых образцах был обнаружен альфа-излучатель ${ }^{235} \mathrm{U}$, который представляет серьезную опасность как для экосистемы, так и для здоровья человека. С помощью ИК-спектроскопии было показано, что для жителей Харьковского региона характерно наличие почечных камней смешанного минерального состава, доминирующим компонентом которого является вевеллит (моногидрат оксалата кальция).

\section{АНАЛІЗ МІГРАЦЙНОЇ ЗДАТНОСТІ ТА КОНЦЕНТРУВАННЯ УРАНУ В ОБ'ЄКТАХ НАВКОЛИШНЬОГО СЕРЕДОВИЩА ТА НИРКОВИХ КАМЕНЯХ ПАЦІЕНТІВ У ХАРКІВСЬКОМУ РЕГІОНІ}

\section{М.П. Дикий, В.М. Лісовий, О.П. Березняк, С.М. Колупаєв, Ю.В. Ляшко, О.П. Медведєва, Д.В. Медведєв, Ю.С. Ходирева}

Проведено гамма-активаційний аналіз на ЛПЕ ННЦ ХФТІ для визначення вмісту природного урану та активності ${ }^{235} \mathrm{U}$ у зразках навколишнього середовища (воді, грунті, водній рослині (гідрофіт)), а також у ниркових каменях пацієнтів. У всіх досліджених зразках був зареєстрований альфа-випромінювач ${ }^{235} \mathrm{U}$, який представляє значну небезпеку як для екосистеми, так і для здоров`я людини. Завдяки методу ІЧспектроскопії було показано, що для мешканців Харківського регіону характерна наявність ниркових каменів змішаного мінерального складу, домінуючим компонентом якого є вевеліт (моногідрат оксалату кальцію). 